\title{
PENGARUH KARAKTERISTIK PETERNAK DAN ADOPSI TEKNOLOGI TERHADAP KEBERHASILAN INSEMINASI BUATAN DI KECAMATAN SINJAI BARAT KABUPATEN SINJAI
}

\section{The Effect of Breeder Characteristics and Technology Adoption on The Success of Artificial Insemination In Sinjai Barat District, Sinjai Regency}

\author{
N.R. Razak ${ }^{1 *}$, Herianto ${ }^{2}$, A.K. Armayanti ${ }^{3}$, dan M.E. Kurniawan ${ }^{3}$ \\ ${ }^{1}$ Jurusan Peternakan, Politeknik Pembangunan Pertanian Gowa \\ ${ }^{2}$ Dinas Peternakan dan Kesehatan Hewan Kabupaten Sinjai \\ ${ }^{3}$ Program Studi Peternakan, Universitas Muhammadiyah Sinjai \\ *e-mail: nurrahmarazak17@gmail.com
}

\section{Received: 2 November 2021; Accepted: 30 November 2021; Published: 25 Desember 2021}

\begin{abstract}
ABSTRAK
Pengembangan dan peningkatan usaha, maka peternak harus berupaya merubah cara berpikirnya dan menumbuhkan karakteristiknya dengan memiliki sejumlah pengetahuan praktis yang berkaitan dengan usaha peternakan. Inseminasi Buatan serta dukungan dari pemerintah daerah pencanangan Inseminasi Buatan (IB) dan Asuransi Usaha Ternak Sapi (AUTS). Saat ini sudah digencarkan oleh pemerintah melalui program UPSUS SIWAB (Upaya Khusus Sapi Induk Wajib Bunting). Upaya UPSUS SIWAB yang dilaksanakan melalui strategi optimalisasi pelaksanaan Inseminasi Buatan (IB). demi tercapainya swasembada pangan asal hewan, sekaligus meningkatkan kesejahteraan peternak. Tujuan untuk mengetahui mengetahui pengaruh karakteristik peternak dan adopsi teknologi terhadap keberhasilan Inseminasi Buatan di kecamatan Sinjai Barat, Kabupaten Sinjai. Hasil penelitian menunjukkan bahwa karakteristik peternak umur, tingkat pendidikan, pengalaman beternak dan adopsi teknologi berpengaruh signifikan secara bersama sama dedangkan secara sendiri sendiri umur dan tingkat pendidikan tidak berpengaruh signifikan serta pengalaman beternak dan adopsi teknologi berpengaruh signifikan terhadap keberhasilan inseminasi buatan.
\end{abstract}

Kata kunci: Umur, tingkat pendidikan, pengalaman beternak, adopsi teknologi

\section{ABSTRACT}

For business development and improvement, farmers must try to change their way of thinking and grow their characteristics by having a number of practical knowledge related to livestock business. Artificial Insemination and support from the local government for the declaration of Artificial Insemination (AI) and Cattle Business Insurance (AUTS). Currently, the government has intensified it through the UPSUS SIWAB program (Special Efforts for Pregnant Cows). UPSUS SIWAB's efforts are carried out through an optimization strategy for the implementation of Artificial Insemination (AI). in order to achieve self-sufficiency in food of animal origin, as well as improve the welfare of farmers. The purpose of this study was to determine the effect of breeder characteristics and technology adoption on the success of Artificial Insemination in the West Sinjai sub-district, Sinjai Regency. The results showed that the breeder's characteristics of age, education level, experience of raising livestock and technology adoption had a significant effect together, while individually, age and education level had no significant effect and experience of farming and technology adoption had a significant effect on the success of artificial insemination.

Keywords: Age, education level, livestock experience, technology adoption

Diterbitkan Oleh,

Unit Penelitian dan Pengabdian Masyarakat, Politeknik Pembangunan Pertanian Gowa

http://ejournal.polbangtan-gowa.ac.id 


\section{PENDAHULUAN}

Permasalahan yang dihadapi dalam bidang peternakan di Indonesia antara lain adalah masih rendahnya produktifitas dan mutu genetik ternak. Keadaan ini terjadi karena sebagian besar peternakan di Indonesia masih merupakan peternakan konvensional, dimana mutu bibit, penggunaan teknologi dan keterampilan peternak relatif masih rendah. Inseminasi buatan merupakan teknologi alternatif yang sedang dikembangkan dalam usaha meningkatkan mutu genetik dan populasi ternak sapi di Indonesia. Salah satu metode untuk meningkatkan produktivitas biologis ternak lokal Indonesia melalui teknologi pemuliaan yang hasilnya relatif cepat dan cukup memuaskan serta telah meluas dilaksanakan adalah mengawinkan ternak tersebut dengan ternak unggul impor (Hastuti, 2008). Pelaksanaan kegiatan Inseminasi Buatan (IB) merupakan salah satu upaya penerapan teknologi tepat guna.

Untuk pengembangan dan peningkatan usaha, maka peternak harus berupaya merubah cara berpikirnya dan menumbuhkan karakteristiknya dengan memiliki sejumlah pengetahuan praktis yang berkaitan dengan usaha peternakan. Hal ini dilakukan melalui pendidikan non formal, belajar berupaya memperoleh berbagai informasi, memanfaatkan berbagai media, memperluas pengalamannya, kreatif, inovatif, dan belajar untuk mengambil keputusan. Peternak sebagai kunci keberhasilan usahanya harus mampu menyerap informasi yang ada. Informasi merupakan faktor yang penting dalam pengkayaan pengetahuan peternak (Tomatala, 2004). Pola pembibitan yang lebih terpadu harus segera dilakukan secara sistematis. Peran pemerintah masih sangat diperlukan dalam era otonomid aerah. Tantangan untuk dapatmen desain pola pembibitan yang terpaduakan sedikit mengalami kesulitan dalam aspek pola pembinaan oleh Dinas Peternakan atau Lembaga terkait.

Pola pembibitan bersifat lintas sektoral dan melibatkan berbagai aspek kepentingan sosial dan ekonomi yang dalam batas batas tertentu tidak dapat dikendalikan oleh unsur birokrasi yang dalam praktek sangat dibatasi oleh tugas dan wewenang administratif daerah. Menyadari kekurangan tersebut, berbagai langkah kebijakan telah ditempuh oleh pemerintah antara lain melalui pengembangbiakan ternak dengan bantuan inovasi baru sepert teknologi Inseminasi Buatan (Pateda, 2010).

Kabupaten Sinjai merupakan salah satu Kabupaten dari Sulawesi Selatan yang dijadikan sentra untuk pengembangan sapi potong dengan teknologi Inseminasi Buatan serta dukungan dari pemerintah daerah pencanangan Inseminasi Buatan (IB) dan Asuransi Usaha Ternak Sapi (AUTS). Saat ini sudah digencarkan oleh pemerintah melalui program UPSUS SIWAB (Upaya Khusus Sapi Induk Wajib Bunting). Upaya UPSUS SIWAB yang dilaksanakan melalui strategi optimalisasi pelaksanaan Inseminasi Buatan (IB). demi tercapainya swasembada pangan asal hewan, sekaligus meningkatkan kesejahteraan peternak.

Populasi Kelahiran Inseminasi Buatan di Kabupaten Sinjai terus mengalami peningkatan dari tahun ketahun, hal ini menunjukkan bahwa pemikiran masyarakat dalam mengadopsi suatu inovasi sudah mulai terbuka karena tingkat pertumbuhan hasil Inseminasi Buatan lebih cepat jika dibandingkan dengan kawin alam dan masyarakat tidak membutuhkan pejantan untuk kawin alam yang terbilang cukup susah karena sapi yang dijadikan pejantan sangat susah untuk didapatkan. Inseminasi Buatan merupakan salah satu teknologi dalam reproduksi ternak yang memiliki manfaat dalam mempercepat peningkatan mutu genetik ternak, mencegah penyebaran penyakit reproduksi yang ditularkan melalui perkawinan alam, meningkatkan efisiensi penggunaan pejantanunggul, serta menurunkan atau menghilangkan biaya investasi pengadaan dan pemeliharaan ternak pejantaninseminasi Buatan (Sugeng, 1997).

Cepat lambatnya peternak mengadopsi inovasi sangat ditentukan oleh faktor internal maupun factor ekternal. Faktor internal misalnya karakteristik peternak (umur, pendidikan, pengalaman beternak dan adopsi teknologi) sedangkan fakkor eksternal misalnya sifat dari inovasi tersebut kerumitan, keuntungan relatif keselarasan inovasi dengan kondisi sosial budaya setempat serta inovasi tersebut dapat dicoba. Permasalahan yang biasanya didapatkan di masyarakat dalam proses adopsi teknologi Inseminasi Buatan bahwa peternak masih takut

Diterbitkan Oleh, 
melakukan Inseminasi Buatan karena proses kelahiran yang sangat susah sehingga dapat menyebabkan kematian pada induksapi tersebut.

\section{METODE PENELITIAN}

Penelitian yang dilakukan menggunakan metode deskriptif kuantitatif yang bertujuan untuk mengetahui karakteristik peternak di Kecamatan Sinjai Barat Kabupaten Sinjai. Jenis penelitian deskriptif kuantitatif yang berupa wawancara, pengamatan secara menyeluruh maupun dengan kajian pustaka karakteristik peternak (umur, tingkat pendidikan, pengalaman beternak).

\section{Metode Pengumpulan Data}

Metode pengumpulan data yang digunakan dalam penelitian ini adalah:

1. Observasi, yaitu pengumpulan data yang dilakukan melalui pengamatan secara langsung terhadap kondisi lokasi penelitian.

2. Wawancara, yaitu pengumpulan data yang dilakukan melalui wawancara langsung dengan peternak

3. Kuisioner yaitu pengumpulan data yang dilakukan dengan menggunakan daftar-daftar pertanyaan yang telah disediakan kepada peternak sapi.

\section{Populasi dan Sampel}

Populasi dalam penelitian ini adalah jumlah peternak yang mengikuti program Inseminasi Buatan di Kecamatan Sinjai Barat, sebanyak 1748 orang.
Berhubung karna populasi yang sifatnya menyebar di antara sembilan Desa tersebut dan cukup berjauhan. Untuk menentukan besarnya jumlah sampel yang digunakan maka digunakan rumus Slovin (Umar, 2001). Jadi sampel minimum yang digunakan pada penelitian ini yaitu sebanyak 94 responden. Adapun Teknik pengambilan sampel yaitu dengan cara Simple Random Sampling yang merupakan bagian dari probability sampling. Teknik pengambilan sampel sendiri dilakukan secara acak.

\section{HASIL DAN PEMBAHASAN}

\section{Keadaan Umum Responsen}

\section{Umur}

Umur merupakan salah satu faktor yang mempengaruhi perilaku dalam melakukan atau mengambil keputusan dan dapat bekerja secara optimal serta produktif. Seiring dengan perkembangan waktu, umur manusia akan mengalami perubahan dalam hal ini penambahan usia yang dapat mengakibatkan turunnya tingkat produktivitas seseorang dalam bekerja. Menurut Badan Pusat Statistik (BPS), berdasarkan komposisi penduduk, usia penduduk dikelompokkan menjadi tiga yaitu: Usia $\leq 14$ tahun : usia muda/usia belum produktif, Usia 15-64 tahun : usia dewasa/usia kerja/usia produktif, dan Usia $\geq$ 65 tahun : usia tua/usia tidak produktif/usia jompo

Keadaan umum responden berdasarkan tingkat umur di Kecamatan Sinjai Barat dapat dilihat pada Tabel 1.

Tabel 1. Klasifikasi responden berdasarkan umur di Kecamatan Sinjai Barat

\begin{tabular}{cccc}
\hline No & Umur Responden (Umur) & Frekuensi (orang) & Persentase (\%) \\
\hline 1 & $10-19$ & 2 & 2 \\
2 & $20-29$ & 13 & 14 \\
3 & $30-39$ & 21 & 22 \\
4 & $40-49$ & 33 & 35 \\
5 & $50-59$ & 20 & 21 \\
6 & $60-69$ & 5 & 5 \\
& Jumlah & 94 & 100 \\
\hline
\end{tabular}

Diterbitkan Oleh, 
Tabel 1 menunjukkan responden di kecamatan Sinjai Barat berusia 40- 49 sebanyak 33 peternak dengan persentase $35 \%$ dan $10-19$ sebanyak 2 peternak. Umur responden termuda yaitu 15 tahun dan tertua 66 tahun. Usia produktif dimulai dari usia 20 sampai 59. Hal ini sesuai dengan pendapat Zainal dan Chris (1991) yang menyatakan bahwa umur antara 20-59 tahun merupakan umur yang produktif, sedangkan umur dibawah 20 tahun merupakan umur yang belum produktif dan dapat dikategorikan sebagai usia sekolah, sedangkan umur di atas 59 tahun titik produktivitasnya telah melewati titik normal dan akan menurun sejalan dengan umur.

Melihat persentase umur pada Tabel 1, maka dapat dikatakan bahwa umur dapat mempengaruhi seseorang dalam mengadopsi suatu inovasi untuk meningkatkan usahatani yang dimilikinya. Hal ini sesuai dengan pendapat Soekartawi (2008) yang menyatakan bahwa petani berusia lebih tua biasanya cenderung sangat konservatif dalam menyikapi perubahan atau inovasi teknologi. Berbeda dengan petani yang berusia lebih muda. Makin muda umur petani, biasanya mempunyai semangat ingin tahu apa yang belum mereka ketahui, sehingga dengan demikian mereka berusaha untuk lebih cepat melakukan anjuran dari kegiatan penyuluhan.

Prabayanti (2010) bahwa seseorang dengan umur produktif biasanya mempunyai semangat untuk ingin tahu tentang berbagai hal yang belum diketahui. Selain itu usia juga mempengaruhi kondisi fisik seseorang. Terkait dengan adanya inovasi, seseorang pada umur non produktif akan cenderung sulit menerima inovasi.

\section{Tingkat Pendidikan}

Tingkat pendidikan seseorang merupakan suatu indikator yang mencerminkan kemampuan seseorang untuk menyelesaikan suatu jenis pekerjaan atau tanggung jawab. Perbedaan tingkat pendidikan akan menyebabkan pula perbedaan cara dan pola pikir peternak dan lembaga dalam mengadopsi berbagai inovasi dan teknologi yang dapat meningkatkan produktifitas dan efisiensi usaha. Klasifikasi responden berdasarkan tingkat pendidikan di Kecamatan Sinjai Barat dapat dilihat pada Tabel 2.

Tabel 2. Klasifikasi responden berdasarkan tingkat pendidikan di Kecamtan Sinjai Barat

\begin{tabular}{cccc}
\hline No & Tingkat Pendidikan & Frekuensi (orang) & Persentase $(\%)$ \\
\hline 1 & SD & 52 & 55 \\
2 & SMP & 19 & 20 \\
3 & SMA & 16 & 17 \\
4 & S1 & 7 & 7 \\
& Jumlah & 94 & 100 \\
\hline
\end{tabular}

Tabel 2 menunjukkan bahwa tingkat pendidikan yang dimiliki oleh masyarakat di Kecamatan Sinjai Barat Kabupaten Sinjai SD sebanyak 55\% dari 52 orang SMP sebanyak 20\% SMA sebanyak $17 \&$, dan S1 sebanyak $7 \%$ telah melanjutkan pendidikan hingga perguruan tinggi. Dapat diketahui bahwa sebagian peternak di Kecamatan Sinjai Barat sudah menyadari akan pentingnya pendidikan. Tinggi rendahnya tingkat pendidikan yang dimiliki oleh responden berpengaruh terhadap tingkat kemampuan dan cara berfikir yang mereka miliki, hal ini sesuai dengan pendapat Lestraningsih dan Basuki (2008) yang menyatakan bahwa, tingkat pendidikan berpengaruh terhadap kemampuan peternak dalam penerapan teknologi. Apabila pendidikan rendah maka daya pikirnya sempit maka kemampuan menalarkan suatu inovasi baru akan terbatas, sehingga wawasan untuk maju lebih rendah dibanding dengan peternak yang berpendidikan tinggi.

\section{Pengalaman Beternak}

Pengalaman beternak merupakan lama waktu yang telah dilalui oleh peternak dalam menjalankan suatu usaha. Semakin banyak 
pengalaman yang dimilki oleh peternak maka akan bijak dalam mengambil keputusan. Pengalaman beternak akan diperoleh seseorang berdasarkan lama mereka bergelut dalam suatu usaha peternakan. Pengalaman beternak merupakan faktor penting yang harus dimiliki oleh seorang peternak untuk memutuskan segala kebijakan yang akan diterapkan dalam usahanya. Klasifikasi responden berdasarkan pengalaman beternak yang ada di Kecamatan Sinjai Barat dapat dilihat pada Tabel 3.

Tabel 3. Klasifikasi responden berdasarkan pengalaman beternak di Kecamatan Sinjai Barat

\begin{tabular}{cccc}
\hline No & Pengalaman beternak & Frekuensi (orang) & Persentase $(\%)$ \\
\hline 1 & $1-10$ & 31 & 32 \\
2 & $11-20$ & 45 & 48 \\
3 & $21-30$ & 14 & 15 \\
4 & $31-40$ & 4 & 4 \\
& Jumlah & 94 & 100 \\
\hline
\end{tabular}

Tabel 3 menunjukkan bahwa keadaan responden di Kecamatan Sinjai Barat Kabupaten Sinjai berdasarkan pengalaman beternak rata-rata pada rentang waktu 11-20 tahun dengan persentase $48 \%$. Pengalaman beternak juga berpengaruh pada skala kepemilikan ternak, sebab semakin lama pengalaman beternak seseorang maka semakin banyak pula pengetahuan yang diketahui oleh peternak yang dapat mendorong perkembangan usaha peternakan. Mastuti dan Hidayat (2008) menyatakan bahwa, semakin lama beternak diharapkan pengetahuan yang didapat semakin banyak sehingga keterampilan dalam menjalankan usaha peternakan semakin meningkat.

Dengan beternak yang cukup lama memberikan indikasi bahwa pengetahuan dan ketrampilan peternak terhadap manajemen pemeliharaan ternak mempunyai kemampuan yang lebih baik. Namun, peternak mengelolah usahanya dengan kebiasaan-kebiasaan lama (semi-ekstensif) yang diikuti dari kebiasaan orang tuanya secara turun- temurun.

\section{Analisis Regresi Linear Berganda}

Adapun yang menjadi variabel pada penelitian ini yaitu terdiri atas variabel bebas (independen) meliputi Karakteristik masyarakat (Umur, Tingkat Pendidikan, Pengalaman Beternak) dan Adopsi Teknologi sementara untuk variabel terikat (dependen) adalah keberhasilan inseminasi buatan. Adapun hasil perhitungan analisis regresi linier berganda dapat dilihat pada Tabel 4.

Berdasarkan Tabel 4 nilai $\mathrm{R}$ menunjukkan korelasi berganda, yaitu korelasi antara antara variabel independen terhadap variabel dependen di Kecamatan Sinjai Barat, Kabupaten Sinjai dapat dilihat dari nilai $(\mathrm{R})$, dimana nilainya adalah 0,234 artinya korelasi antara variabel independen umur, tingkat pendidikan, pengalaman beternak dan adopsi teknologi terhadap variabel dependen keberhasilan inseminasi buatan secara bersama sama memiliki hubungan yang tidak terlalu mempengaruhi terhadap variabel dependen. Hal ini sesuai dengan pendapat Sugiyono (2010) yang menyatakan bahwa pedoman untuk memberikan interperensi koefisien korelasi yaitu 0,00 (sangat rendah) sampai 1,00 (sangat kuat).

Nilai $\mathrm{R}^{2}$ memberikan gambaran besarnya kontribusi pengaruh variabel independen umur, tingkat pendidikan, pengalaman beternak dan adopsi teknologi terhadap variabel dependen keberhasilan inseminasi buatan yaitu sebesar 0,234. Angka ini akan diubah ke bentuk persen, artinya persentase sumbangan pengaruh variabel independen umur, tingkat pendidikan, pengalaman beternak dan adopsi teknologi terhadap variabel dependen keberhasilan inseminasi buatan sebesar $23,4 \%$, sedangkan sisanya sebesar $76,6 \%$ artinya masih ada faktor lain yang mempengaruhi keberhasilan inseminasi buatan yang tidak dimasukkan ke dalam model ini.

Diterbitkan Oleh, 
DOI: 10.52625/j-agr-sosekpenyuluhan.v17i2.210

Tabel. 4 Rekapitulasi hasil analisis regresi linier berganda

\begin{tabular}{|c|c|c|c|c|c|}
\hline Variabel penelitian & $\begin{array}{c}\text { Koefisien } \\
\text { Regresi }\end{array}$ & $\begin{array}{l}\text { Koefisien } \\
\text { Korelasi (r) }\end{array}$ & T Hitung & Sig. & Keterangan \\
\hline \multicolumn{6}{|l|}{ Keberhasilan IB (Y) } \\
\hline \multirow{2}{*}{$\begin{array}{l}\text { Umur (X1) } \\
\text { Tingkat pendidikan (X2) }\end{array}$} & $-0,009$ & \multirow{2}{*}{$\begin{array}{l}-0,129 \\
-0,421\end{array}$} & $-1,396$ & 0,166 & \multirow{2}{*}{$\begin{array}{l}\text { Non Signifikan } \\
\text { Non Signifikan }\end{array}$} \\
\hline & $-0,081$ & & $-1,506$ & 0,136 & \\
\hline $\begin{array}{l}\text { Pengalaman } \\
\text { (X3) }\end{array}$ & 0,019 & 0,058 & 2,356 & 0,021 & Signifikan \\
\hline Adopsi Teknologi (X4) & 0,051 & 0,980 & 3,478 & 0,001 & Signifikan \\
\hline $\begin{array}{l}\text { F Hitung }=6.789 \\
\text { F Tabel }=2.47 \\
\text { T Tabel }=1.67\end{array}$ & & $\begin{array}{l}\text { R Square }=0.234 \\
\text { Constanta }=29.408 \\
\text { Signifikan pada } \alpha=\end{array}$ & $\begin{aligned} & R= \\
&=0.05\end{aligned}$ & & \\
\hline
\end{tabular}

\section{Uji F atau Uji Pengaruh Secara Simultan}

Untuk mengetahui pengaruh variabel bebas (independen) terhadap variabel terikat (dependen) secara bersama sama ( simultan) maka dilakukan uji F (Sugiyono, 2010), dalam analisa ini dilakukan dengan membandingkan antara nilai $F_{\text {hitung }}$ dengan $F_{\text {tabel }}$, pada taraf kepercayaan $95 \%$ atau $\alpha=0.05$. jika nilai $F_{\text {hitung }}$ lebih besar dari pada $F_{\text {tabel }}$, maka dengan demikian variabel bebas (independen) secara bersamaan berpengaruh nyata atau signifikan terhadap variabel terikat (dependen).

Dari hasil perhitungan diperoleh $F_{\text {hitung }}$ sebesar 6,789 sedangkan nilai $F_{\text {tabel }} \quad 2,47$ berarti $F_{\text {hitung }}$ lebih besar dari $F_{\text {tabel }}$. (6,789> 2,47). Hal ini menunjukkan bahwa variabel intensitas umur, tingkat pendidikan, pengalaman beternak dan adopsi teknologi secara bersama sama berpengaruh signifikan terhadap keberhasilan inseminasi buatan di kecamatan Sinjai Barat Kabupaten Sinjai. Dari nilai nilai di Tabel 9, dapat dimasukkan dalam rumus regresi linier berganda sebagai berikut:

$$
Y=\underset{(0.058 X 3)+(0.051 X 4)}{29.408+(-0.009 X 1)}+(-0.081 X 2)+
$$

\section{Uji T atau Uji Pengaruh Secara Parsial}

\section{Setelah melakukan pengujian pengaruh variabel independen secara simultan maka selanjutnya dilakukan pengujian pengaruh variabel}

independen terhadap variabel dependen secara parsial atau sendiri-sendiri adapun pengujian dilakukan dengan menggunakan uji t. adapun pengujian dilakukan yaitu Jika $T_{\text {hitung }}$ lebih besar ( > ) dari $T_{\text {tabel }}$ pada signifikan $5 \%$ berarti secara parsial variabel independen berpengaruh nyata terhadap variabel dependen. Yang artinya Ho ditolak. Jika $T_{\text {hitung }}$ lebih kecil $(>)$ dari $T_{\text {tabel }}$ pada signifikan $5 \%$ berarti secara parsial variabel independen tidak berpengaruh nyata terhadap variabel dependen. Yang artinya Ho diterima.

Untuk melihat pengaruh secara sendiri sendiri atau parsial masing masing variabel independen akan diuraikan sebagai berikut:

\section{Pengaruh Umur (X1) terhadap Keberhasilan Inseminasi Buatan di Kecamatan Sinjai barat kabupaten Sinjai}

Hasil perhitungan di peroleh $T_{\text {hitung }}$ umur (X1) sebesar $-1,396$ dan nilai $T_{\text {tabel }} 1,67(\alpha=$ $0,05)$. Karena nilai $T_{\text {hitung }}$ lebih kecil dari $T_{\text {tabel }}$ $(-1,396<1,67)$ maka dapat dikatakan bahwa secara parsial umur (X1) tidak memberikan pengaruh atau hubungan yang signifikan dengan keberhasilan inseminasi buatan.

Umur peternak di Kecamatan Sinjai Barat memiliki umur yang produktif tapi peternakan bukan satu satunya pekerjaan mereka, beternak adalah pendapatan sampingan mereka. Hal ini tidak

Diterbitkan Oleh, 
sesuai dengan pendapat Soekartawi (2008) menyatakan semakin muda umur petani biasanya mempunyai semangat untuk ingin tahu apa yang belum mereka ketahui, sehingga dengan demikian mereka berusaha untuk lebih cepat melakukan anjuran dari kegiatan penyuluhan. Umur petani adalah salah satu faktor yang berkaitan erat dengan kemampuan kerja dalam melaksanakan kegiatan usahatani, umur dapat dijadikan tolak ukur dalam melihat aktivitas seseorang dalam bekerja dimana dengan kondisi umur yang masih produktif maka kemungkinan besar seseorang dapat bekerja dengan baik dan maksimal.

\section{Pengaruh Tingkat Pendidikan (X2) terhadap Keberhasilan Inseminasi Buatan di Kecamatan Sinjai Barat Kabupaten Sinjai}

Hasil perhitungan di peroleh $T_{\text {hitung }}$ tingkat pendidikan $(X 2)$ sebesar --1,506 dan nilai $T_{\text {tabel }} 1,67(\alpha=0,05)$. Karena nilai $T_{\text {hitung }}$ lebih kecil dari $T_{\text {tabel }}(-1,396<1,67)$ maka dapat dikatakan bahwa secara parsial tingkat pendidikan (X2) tidak memberikan pengaruh atau hubungan yang signifikan dengan keberhasilan inseminasi buatan.

Pendidikan tidak berpengaruh secara langsung terhadap tingkat adopsi karena pendidikan yang dimaksud ini adalah pendidikan formal. Dalam usaha ternak sapi tentu lebih banyak membutuhkan pendidikan informal terutama penyuluhan dan pelatihan agar dapat meningkatkan pengetahuan, sikap dan keterampilan peternak dalam usaha ternak sapi potong. Hasil penelitian ini sesuai dengan pendapat Juita (2005) dalam Utama (2014) yang menjelaskan bahwa tingkat pendidikan formal tidak berhubungan nyata dengan tingkat adopsi teknologi. Dijelaskan bahwa hal ini disebabkan karena untuk menerapkan suatu teknologi dalam usahataninya, petani tidak harus memilki tingkat pendidikan formal yang tinggi. Petani tentunya memiliki keterampilan dan pengetahuan yang berbeda, dimana tidak semua petani berpendidikan tinggi memiliki keterampilan dan pengetahuan yang lebih tinggi dibandingkan petani yang tingkat pendidikannya rendah.

\section{Pengaruh Pengalaman Peternak (X3) terhadap Keberhasilan Inseminasi Buatan di Kecamatan Sinjai Barat Kabupaten Sinjai}

Hasil perhitungan di peroleh $T_{\text {hitung }}$ pengalaman beternak (X3) sebesar 2,356 dan nilai $T_{\text {tabel }} 1,67(\alpha=0,05)$. Karena nilai $T_{\text {hitung }}$ lebih besar dari $T_{\text {tabel }}(2,356>1,67)$ maka dapat dikatakan bahwa secara parsial pengalaman beternak (X3) memberikan pengaruh atau hubungan yang signifikan dengan keberhasilan inseminasi buatan.

Pengalaman beternak mempengaruhi tingkat adopsi karena keputusan adopsi peternak sangat didukung oleh pengalaman yang telah mereka peroleh selama ini. Apabila inovasi yang ditawarkan ternyata sesuai atau hampir mendekati dengan cara-cara yang selama ini dilakukan maka akan mempermudah proses adopsi. Namun apabila inovasi yang ditawarkan belum pernah mereka lakukan akan membutuhkan waktu hingga peternak bersedia untuk mengadopsi. Menurut Fauziah dan Tumpubolon (1991) dalam Siregar (2009), bahwa pengalaman seseorang dalam berusaha tani berpengaruh terhadap penerimaan dari luar, lamanya pengalaman diukur mulai sejak kapan peternak itu aktif secara mandiri mengusahakan usaha taninya tersebut.

\section{Pengaruh Adopsi Teknologi (X4) terhadap Keberhasilan Inseminasi Buatan di Kecamatan Sinjai Barat Kabupaten Sinjai}

Hasil perhitungan di peroleh $T_{\text {hitung }}$ adopsi teknologi (X3) sebesar 3,478 dan nilai $T_{\text {tabel }} 1,67(\alpha=0,05)$. Karena nilai $T_{\text {hitung }}$ lebih besar dari $T_{\text {tabel }}(3,478>1,67)$ maka dapat dikatakan bahwa secara parsial adopsi teknologi (X3) memberikan pengaruh atau hubungan yang signifikan dengan keberhasilan inseminasi buatan.

Pernak yang telah mengadopsi teknologi menganggap bahwa adopsi teknologi tersebut banyak keuntungan bagi petani baik secara teknis, ekonomis, maupun sosial-psikologis. Secara ekonomis adopsi teknologi dapat meningkatkan populasi ternak dan memperbaiki mutu genetik ternak meskipun secara teknis pelaksanaan IB 
cukup rumit dan memerlukan biaya yang yang cukup mahal. Semakin menguntungkan suatu inovasi bagi petani maka akan semakin mudah untuk diadopsi. Adopsi teknologi IB juga dianggap sesuai dengan kebutuhan dan kemampuan ekonomi petani yang telah mengadopsi teknologi tersebut. Selain itu, inovasi tersebut juga dianggap tidak mencemari lingkungan sehingga sesuai dengan kondisi lingkungan.

Peternak yang telah menerapkan adopsi IB pada umumnya telah menyadari bahwa IB memberikan keuntungan bagi petani. Sebaliknya, responden yang tidak menerapkan IB menganggap bahwa IB kurang efektif dan tidak praktis jika dibandingkan dengan kawin alami yang tidak memerlukan biaya mahal. Rogers (2003), menyebutkan adopsi adalah keputusan untuk menggunakan sepenuhnya ide baru sebagai cara bertindak yang paling baik. Terkait dengan penelitian ini berarti adopsi yang dimaksudkan adalah keputusan petani untuk menggunakan Inseminasi Buatan.

\section{KESIMPULAN}

Berdasarkan hasil dan pembahasan penelitian, maka dapat ditarik kesimpulan bahwa karakteristik peternak (umur, tingkat pendidikan, pengalaman beternak) dan adopsi teknologi secara bersama sama (simultan) berpengaruh signifikan terhadap keberhasilan inseminasi buatan. Sedangkan secara sendiri sendiri (parsial) umur dan tingkat pendidikan tidak berpengaruh signifikan terhadap keberhasilan inseminasi buatan serta pengalaman beternak dan adopsi teknologi berpengaruh signifikan terhadap keberhasilan inseminasi buatan.

\section{DAFTAR PUSTAKA}

Hastuti, D. 2008. Tingkat keberhasilan inseminasi buatan sapi potong di tinjau dari angka konsepsi dan service per conceptio. Fakultas Pertanian Universitas Wahid Hasyim. Mediagro. Vol 4 (2): 12-20.

Mastuti, S dan Hidayat, N. N. 2008. Peranan Tenaga Kerja Perempuan Dalam Usaha Ternak Sapi Perah. Jurnal of animal production: Purwokerto.

Pateda, S. Y. 2010. Tingkat adopsi petani terhadap teknologi inseminasi buatan pada sapi di Kecamatan Paguyaman. Fakultas IlmuIlmu Pertanian. Universitas Negeri Gorontalo. Saintek. Vol 5 (1): 1-6.

Prabayanti, Harning. 2010. Skripsi Faktor-faktor yang Mempengaruhi Adopsi Biopestisida oleh Petani di Kecamatan Mojogedang Kabupaten Karanganyar. Fakultas Pertanian Universitas Sebelas Maret. Surakarta.

Roger, E. M. 1995. Diffusion of Innovation.Fourth Edition. Free Press. New York.

Siregar, S. Amri.2009. Analisis Pendapatan Peternak Sapi Potong Di Kecamatan Stabat Kabupaten Langkat. Skripsi Jurusan Ilmu Produksi Ternak Fakultas Peternakan Universitas Sumatera Utara.

Soekartawi. 2008. Prinsip Dasar Komunikasi Pertanian. Jakarta: UI Press.

Sugeng, Y. B. 1997. Sapi Potong. Penerbit CV. Yasa Guna. Jakarta.

Tomatala, G. S. J. 2004. Pemanfaatan Media Komunikasi Dan Perilaku Usaha Peternak Sapi Potong. Kasus Kecamatan Sukanagara, Kabupaten Cianjur. [Tesis]. Bogor: Institut Pertanian Bogor. 